\title{
Introduction
}

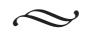

$\mathrm{T}$ he mood is shifting in the contemporary globalisation debate. Only a few years ago, talk of the contested and politicised nature of globalisation would have met with scepticism from those who emphasise the sheer economic power of globalising forces. The orthodox popular and academic representations of globalisation have for several decades sustained the image of a powerful economic and technological bulldozer that effortlessly shovels up states and societies. The very discourse of the 'competition state' (Cerny, 1990) effectively sanitised the globalisation process, removing the messiness of politics and leaving only the 'right and necessary' policy measures. As the millennium turned, the picture began to change so that we now begin to see partial glimpses of the push and shove of a social and political contestation that was, in truth, always present. Now we see the news media popularising debates about the power of multinational corporations (MNCs), the plight of the global economy's 'new slaves' and the 'anti-globalisation' protests (Klein, 2000; Bales, 1999; British Broadcasting Corporation (BBC), Panorama, 2000; Channel 4, 2000). The effect is to bring less comfortable and optimistic images of globalisation to our armchairs. At the same time, scholars within international political economy (IPE), international relations (IR) and sociology have called for the essence of politics to be restored to our understandings of globalisation and restructuring (Marchand and Runyan, 2000; Hay and Marsh, 1999; Bauman, 1998; Beck, 2000a).

This book acknowledges and develops the emergent challenge to the economic and technologically determinist representations of globalisation. It is critical of the 'globalist' representations of transformation as an imperativedriven and inexorable process. For people in their everyday lives, there is perhaps no sphere of social life so consistently bombarded with globalist accounts as that of production and work. For states, such a reading reinforces the imperative of a policy agenda that creates a competitive and capitalfriendly environment for MNCs. Firms are cast as the primary agents of global change as they restructure towards the ultimately 'lean' and 'flexible' organisation. The combined restructuring activity of states and firms is presented as a fait accompli that demands prescribed responses from individuals and social 
groups. Competition states, lean production systems and flexible workers become the dominant mantra in the grip of an unstoppable globalising process.

Though broadly supportive of the critical turn that has been taken to counter the globalist dominance, this book also marks a departure from the central thrust of these contributions. Those who have sought to counter the economism and determinism of orthodox accounts have tended to focus on restoring agency to explanations of globalisation. Globalisation is represented as a project that is driven by the conscious political actions of identifiable individual and collective agents. In contrast to the globalist emphasis on technological and economic process, here we have globalisation as either promoted or resisted by governments within distinctive national capitalisms (Hirst and Thompson, 1996; Weiss, 1998), by a transnational class with common interests in a neo-liberal global order (Gill, 1995a, Van der Pijl, 1984), or by new social movements engaged in an anti-globalisation struggle (Falk, 1999). While such diverse perspectives have restored political agency to the globalisation debate, I argue that there remains too little attention paid to the contested and contradictory dynamics of social change.

This book develops a perspective that views globalisation as, in significant part, contested through and contingent upon structured social practices. Globalisation is imbued with a contingency that rests upon the diverse concrete experiences, interpretations and meanings that are intertwined with the dynamics of transformation. From this perspective, it is highly problematic to assume that state-societies will simply absorb and adapt to global imperatives, or that firms adopt convergent global strategies in different historical contexts, or that workers attribute common meanings to the discourses of flexibility that confront them. Globalisation, cast in this light, is not a single, universal and homogenising process, nor is it a clearly identifiable strategic project. Rather, it is uniquely understood and experienced by people in the context of their known and familiar social practices. To this end, the chapters that follow integrate theoretical discussion of the concept of globalisation with the study of the debates, contests and compromises that are taking place in the restructuring of production and work.

\section{Perspectives on globalisation}

In much of the literature on globalisation the primary focus has been on outlining the various aspects or dimensions of transformation in, for example, finance, production, culture, the state and technology, that combine to constitute an identifiable process of change (Amin et al., 1994; Waters, 1995; Jones, 1995). In identifying these aspects, the first order question has been 'what is globalisation?'. That is to say, the central guiding objective has been to evaluate the evidence of the extent and nature of globalisation in each of the spheres. This has served a useful function in that it has revealed the unevenness of globalisation as it cuts across the multiple layers of social life. 
However, the 'what is it' question does limit inquiry when we consider that the aspects or layers of globalisation are selected, defined and explained in divergent ways so that both the theory and the practice of globalisation could now be said to be contested (Scholte, 2000: 12; Amoore, 2000: 200; O'Brien et al., 2000: 2-6). With this caveat in mind, perhaps the only answer to the pressing contemporary question 'what is globalisation?' can be 'it depends on how you look at it'. Framed in this way, the first order question becomes 'how has the problem been approached, interpreted and understood?'. The singularity and universality that so often surrounds ideas about globalisation is replaced by the possibility of multiple and multi-layered conceptions, each with a distinctive epistemological and ontological commitment.

It is only in the most recent phase of the globalisation debate that scholars have begun to seriously address the question of divergent conceptions of globalisation. This has tended to take the form of the development of typologies or categorisations of perspectives on globalisation. Held et al. (1999: 2-10) have developed a threefold typology of perspectives - the 'hyperglobalists', 'sceptics' and 'transformationalists. The typology is based upon the divergences that exist between accounts of the extent of globalisation and, in particular, the implications for nation-states. Thus, for the hypergloblists, economic and political power becomes 'denationalised' and 'borderless' in the face of extensive global forces (1999: 3). By contrast, the sceptics share the view that globalisation is an overstated and convenient myth that facilitates the implementation of unpopular policies, effectively extending state power (1999: 6). For the transformationalists, the extent of globalisation is uneven and multilayered as national governments reconstitute and restructure their power in response. Within this typology, the focus on the intensity and extensity of globalisation does result in some rather incongruous groupings. For example, Stephen Gill (highly critical of neo-liberal policies) is referenced alongside Kenichi Ohmae (supportive of neo-liberal policies) on the grounds that they share a hyperglobalist account of the emergence of a global economy (1999: 4). They do, of course, have very different conceptions of how we produce knowledge about the global economy (GPE), or indeed whether it is the global economy or the global political economy that is the object of analysis. The Held et al. typology does, to an extent, limit the analysis of epistemological and ontological divergence in the globalisation debate.

A second influential typology of perspectives has been that advanced by Jan Aart Scholte (2000). This typology categorises the perspectives according to their view of the nature of the globalisation process - globalisation as internationalisation, liberalisation, universalisation, westernisation or deterritorialisation. It is argued that the first four perspectives cannot adequately capture the nature of contemporary globalisation because they reduce it to pre-existing processes. Scholte favours 'deterritorialisation' as an account of globalisation that emphasises 'far-reaching change in the nature of social space' (2000: 46). His rejection of the first four perspectives reinforces his own 
perspective on globalisation as the transformation of social relations and social space. Scholte's important contribution has been to bring consideration of globalisation out of the realms of 'economic forces' and into the realm of society and social relations. However, his typology of perspectives does not bring us any closer to considering why globalisation is represented in certain ways in particular settings, and at specific historical moments. Though he argues that the first four perspectives 'cover most academic, official, corporate and popular discussion of things "global"' (2000: 46), he does not ask why this might be so. Why is globalisation most commonly defined as a process of universalisation or liberalisation, for example? Why do opposing perspectives seek to 'put globalisation back in its box' by defining it as nothing more than internationalisation? What are the implications of the framing of the globalisation debate for our understanding of the contemporary global problematic?

In order to address such questions we would need a typology that helps us to think about the relationship between conceptions of globalisation and particular sets of interests in the framing of restructuring discourse. We would need to consider the different perspectives on globalisation as distinctive constructions of knowledge that have significant implications for what we see - and importantly what we do not see - in contemporary processes of restructuring. Below I advance a threefold typology of perspectives on globalisation, each of which has particular implications both for the study of global change and for the restructuring discourse that emerges in production and work. I do not suggest that these perspectives are either internally coherent and cohesive, or entirely discrete and separate entities. They are simply constructions that aid thought about the relationship between particular modes of knowledge about global change, and the 'common sense' that emerges to deal with that change via a programme of restructuring.

\section{Process}

Under the predominant process perspective, globalisation is a master concept that is used to capture material and institutional transformations across contemporary economy, politics and society. In broad terms it encapsulates the orthodox representation of globalisation, one that can be found in the statements of national governments, international organisations and media commentators. ${ }^{1}$ Globalisation is cast in teleological terms as the inevitable outcome of the expansionary ambitions of a global market economy and the transnationalisation of technologies (Amoore et al., 1997). In this vision, states, societies and firms have no alternative but to conform and compete amidst processes of change that occur above and beyond them. The social costs of globalisation are commonly presented either as the temporary problems of transition, or as the inevitable short-term losses in a process that will yield benefits in the longer term.

The process perspective on globalisation has done much to inform 
dominant common sense understandings of transformation in the everyday practices of work. The discursive representation of globalisation as an inexorable process enables particular neo-liberal deregulatory interventions to be made and legitimated. So, for the Organisation for Economic Cooperation and Development (OECD) 'the globalisation process requires economies to be more adaptable and workers more willing to change' (1996: 13). For the World Bank: 'Governments and workers are adjusting to a changing world. The legacy of the past can make change difficult or frightening. Yet realization of a new world of work ... is fundamentally a question of sound choices in the international and the domestic realm' (1995: 11).

A similar vocabulary of globalisation and the imperative of transformation in the form and nature of work can be found in Group of Seven (G7) government policy documents, International Monetary Fund (IMF) structural adjustment programs, management journals and corporate strategy documentation. Here the message is that in order to respond effectively to globalisation it is necessary for production costs to be reduced through the removal of barriers to the free market in factors of production - predominantly in labour. Globalisation is cast as an indomitable process, equated with a shift to new forms of work organisation in line with lean production, just-intime (JIT), teamwork and kaizen. Workers are assumed to move towards more flexible working practices and 'atypical' forms of employment such as parttime, temporary, zero-hours and fixed contracts, outsourcing and homeworking. ${ }^{2}$ This reading treats labour as a commodity that must be restructured in line with global logics. The concrete transformation of social practices is not problematised and the whole process is sanitised of politics. Indeed, it is those societies and workers who fail to adapt to the new realities who are perceived to incur the 'costs of inaction' (OECD, 1996: 21). All distinctive social practices are subsumed by a single global 'best practice' of flexibility. Hence, any discussion of politics is confined to an instrumental role in implementing prescribed reforms. The globalisation process is taken as given, and what Robert Cox refers to as a 'problem-solving' mode of knowledge is generated to 'deal effectively with sources of trouble' (1996: 88).

\section{Project}

When broadly represented as a form of 'project', globalisation is tightly interwoven with the liberal ideological and neo-classical economic doctrines in whose name powerful actors seek to restructure the material and institutional bases of the contemporary world order. ${ }^{3}$ Globalisation is given concrete expression in and through the various restructuring projects that are carried out under the neo-liberal banner. From the field of IPE it is possible to distinguish a number of schools of thought that contribute to the impression of an identifiable project of global transformation. First, what might be termed the 'transnational school' identify transnational interests that consciously act to produce 
and reproduce a globalised economy. Such interests may take the form of a global elite or ruling class whose conscious actions become a directive, strategic element within globalising capitalism' (Gill, 1994: 179). In a similar representation, the project of globalisation may be viewed as driven by the expansionary ambitions of MNCs (Stopford and Strange, 1991; Sklair, 1998). Transformations in production and work are thus viewed as central to a strategy of global capitalism pursued by corporate actors, a range of international institutions such as the World Trade Organisation (WTO), IMF and Trilateral Commission (Gill, 1990; Overbeek, 1990), together with government interests, that may constitute some form of class alliance (Van der Pijl, 1984; Sklair, 2001).

Second, a broad 'national capitalisms school' represents globalisation as overstated, mythical and rooted in the institutions and actions of national authorities. The world economy is held to be essentially international or regional rather than global and thus can be shaped or directed by the policymakers and institutions of competing nation-states and regions (Zysman, 1996; Weiss, 1998; Albert, 1993; Hirst and Thompson, 1996). In terms of the restructuring of production and work this implies that embedded systems of production and industrial relations give distinctive character to divergent national restructuring pathways (Crouch and Streeck, 1997; Ruigrok and van Tulder, 1995).

There are, of course, fundamental differences between the approaches taken by the above scholars. If we take Held et al.'s (1999: 3-5) schema, for example, we would identify both Stephen Gill and Susan Strange with a 'hyperglobalist' position, while Linda Weiss and Graeme Thompson would stand at the opposed 'sceptical' pole. However, in terms of ontology, Susan Strange's work on production has more in common with Winfried Ruigrok's work than with Kenichi Ohmae's work (a fellow globalist). Identified as theorists united by their attention to an emergent global project, this perspective demonstrates that globalisation can and should be analysed in terms of the restructuring done in its name. Furthermore, adherents to the project perspective tend to normatively oppose neo-liberal programmes of restructuring and to seek out the political space for alternatives amidst structural constraints. However, the politics of globalisation is presented as coherently designed and directed by rational collective agents. These agents, whether MNCs, classes or states, are imbued with a unitary identity that is defined by the shared project itself. The tensions, contests and conflicts that surround the form of the project are seriously underestimated. The project perspective can tell us much about the elite actors who contribute to a discourse of global restructuring, but little about the everyday forms of thought and action that characterise the nature of that restructuring.

\section{Practice}

The central terrain of the globalisation debate has been occupied by the disputes between those who claim that globalisation is essentially inexorable 
(the process perspective) and those who claim that globalisation is driven by the purposeful actions of individual and collective agents (the project perspective). The difficulty is that globalisation may well take on both these dynamics simultaneously, and to a differentiated degree in the experiences and practices of people in specific historical contexts and social spaces. So, how might it be possible to capture the contested and highly contingent nature of contemporary global transformation? The argument to be made in this book is that a third perspective - what I term a 'practice' perspective, can illuminate the tensions, contradictions and politics of globalisation that are left in shadow by many existing frameworks of analysis. A number of scholars have begun to map out a perspective that represents globalisation in terms of emergent patterns of globalised social relations and the structured social practices that make these possible (see Langley, 2002). For Jones, the contemporary world is characterised by a 'multiplicity of purposes' that expose the controversial, incomplete and potentially reversible nature of globalisation (2000: 245). In the same volume Germain posits that 'globalization is as inherently contested as a "reality" as it is as a concept or representation of that reality' (2000: xiii). The common thread here is that what we call globalisation is best understood as representative of sets of complex and often contradictory globalising social practices.

It is, however, difficult to find among the various IPE perspectives on global social practices, a genuine effort to explore the normal, commonplace or everyday social practices that make up peoples' experiences of life in a proclaimed global era. Existing avenues into globalisation as social practice have tended to focus almost exclusively on the social practices of elite groups whose actions produce direct effects in the GPE - for example, bankers, corporate managers, politicians and media actors, among others. An understanding of the role of such practices is undoubtedly crucial in the mapping of the contours of global social change. However, the argument to be made here is that globalisation is experienced, given meaning, reinforced and/or challenged in the everyday social practices of individuals and groups at multiple levels, from state-societies and MNCs through to the routine practices of the workplace.

The development of a practice perspective on globalisation, I will argue, follows a 'new' or 'heterodox' approach to IPE in its challenge to the dichotomies of state/market, domestic/international, public/private and local/ global (see Murphy and Tooze, 1991; Amin et al., 1994). Social practices by their nature intersect and cut across these dichotomies. This may occur through direct means such as the use of transborder communications in the organisation of global production, or via indirect means such as the emergence of a 'global consciousness' that connects discrete social practices through global frameworks of thought (Scholte, 2000: 54). James Rosenau has, for example, argued for the consideration of the 'micro-macro' dynamics of contemporary transformation (1997: 59). Tim Sinclair has called for the theorisation of the relationships between ordinary everyday lives and wider 
structural change, to reveal the international political economy of the commonplace' (1999: 165). Matt Davies and Michael Niemann have explored the means by which globalised social relations are produced in the 'daily practices of workers, families or consumers' (2000: 6). Feminist scholars have encouraged reflection on concrete everyday experiences in order to make sense of the 'abstract structure known as the international political economy' (Enloe, 1989: 4; see also Marchand and Runyan, 2000).

Considered through the lens of a practice perspective, globalisation is characterised by contests over the reality and representation of social change. Such contestation can and does take the strategic and organised forms of promotion and resistance highlighted by the project perspective. However, the oppositions and tensions of global restructuring are also present in everyday life. It is helpful to consider the everyday nature of globalisation in terms of contradictory relationships between 'near' and 'far'. For Bauman, the 'near' is characterised as '... primarily that which is usual, familiar and known to the point of obviousness; something seen, met, dealt or interacted with daily, intertwined with habitual routine and day-to-day activities' (1998: 13).

This image of nearness and familiarity can be contrasted with the 'far' as something that is unusual, unfamiliar and unknown to the point of being obscure and extraordinary. By the very nature of globalisation as a 'real or perceived intensification of global interconnectedness' (Held et al., 1999: 2), it is the confrontation and assimilation of near and far that mark the restructuring of government policies, corporate strategies and the everyday practices of the workplace.

Viewed from the perspective of the practices of everyday life, transformations in production and work bring the globalisation debate into commonplace experience. Productive and working practices lie at the heart of capitalist social relations and have provided the focus for debates surrounding the need for adaptation and change. There are indications that the manifestations of global change in the workplace are beginning to be considered more closely by scholars from across disciplinary divides (see Panitch, 2001; Leisink, 1999; Beck, 2000b). It is my view that the restructuring of work is a critical terrain on which the current and future shape of globalisation will be contested. While IPE has appeared comfortable with the theoretical and empirical study of the firm, it has been much less comfortable with the study of labour and work. Meanwhile, MNCs increasingly have become fractured entities, 'outsourcing' their production so that work takes place in sites that have become invisible to IPE inquiry. Where labour and work have been acknowledged in the globalisation debate this has tended to be confined to the study of trade unions and their potential as new social movements. This book proposes that production and work be considered within and across multiple interrelated layers of restructuring - state-societies, firms and workers. Within each of these layers the restructuring of productive and working practices is experienced in diverse ways, varying in its meaning, interpretation and implications. 
This book develops a practice-centred view of globalisation in order to make visible two central interrelated features of the contemporary global restructuring of production and work. First, globalisation does not exist independently of the meanings that are imputed to it by policymakers, corporate strategists, workers, unions, social groups and citizens. This is not to say that there are no structural features of globalisation, but that even the identifiable forces of global financial markets, transborder technologies and global production have vastly differential effects and elicit distinctive patterns of accommodation and resistance. I explore the social and political-economic contests that characterise the distinctive British 'hyperflexible' and German 'flexi-corporatist' approaches to the restructuring of production and work. Robert Cox identifies the tensions within and between the German and British political economies as a 'proving ground' for future world order (1993: 286). The historical context that is reflected in state-societal institutions, norms and practices is not ruptured by globalisation. Rather, it provides one of many frames of reference within which questions are raised, responses are negotiated, and social groups find themselves included or excluded. In doing this, I suggest an alternative value for so-called 'models of capitalism'. Conventionally conceived, national models of capitalism have been variously used to refute globalist claims, to bolster claims to a 'nicer', 'friendlier' socialdemocratic mode of capitalism, or to offer best-practice examples to be emulated and transposed. In my analysis, state-societal contexts are identified merely as 'ideal types' (Cox, 1987: 4-5) of the patterns of compromise, tension and conflict that define a programme of global restructuring. Despite the apparent intractability and dominance of the neo-liberal model of restructuring, it is important to challenge the notion that there is normative unanimity on the model within and across state-societies.

The second key feature of global restructuring that is revealed by a practice perspective is the disruption and contestation that suffuses a restructuring programme as it enters the everyday lives of workers. While IPE studies of the globalisation of production have focused almost exclusively on the $\mathrm{MNC}$, industrial relations scholars have revealed the concrete manifestations of flexibility in the workplace, directly connecting workplace to world order (Harrod, 1997a; Leisink, 1999). A focus on the workplace reveals the tensions that permeate the juxtaposition of near and far as established working practices confront demands for change based on some distant and unfamiliar 'best practice'. Such tensions are exacerbated as the restructuring of working practices create new patterns of inclusion and exclusion, reinforcing or challenging prevailing social power relations. The strategic projects of restructuring may be undermined via 'silent resistance' (Cheru, 1997: 153) and tacit opposition (Scott, 1990), 'blunting the action' in a Polanyian 'double movement' (1957: 76). Capturing the vacillations of global restructuring serves to challenge economistic and teleological accounts, restoring the human and political essence of globalisation. 


\section{Structure of the book}

Chapter 1 explores the conceptions of globalisation and restructuring on which the discourse of labour flexibility is based. Of course, entire books have been devoted to the subject matter of globalisation alone. However, this chapter explores the particular representation of globalisation as an indomitable process that demands specific restructuring responses. The analysis is focused on five defining aspects of the process-centred view of globalisation: exogenous transformative forces, disciplinary imperatives, historical convergence, social prescription and the death of conflict. I argue that these guiding assumptions about the nature and form of contemporary social change have much in common with the modernisation thesis of the industrial society school. Rather than constituting a fundamental break with past practices, the global process model of social change has recast a set of ideas that are deployed to legitimate a programme of labour flexibilisation. The contemporary fixation with flexibility in work and labour is effectively legitimated and perpetuated via a discursive attachment to representations of a natural, automatic and imperative process of globalisation. Such representations have enabled the restructuring of work to be undertaken in a depoliticised atmosphere of 'essential' management strategies. The chapter, therefore, presents the case for a renewed emphasis on the social power relations and social contests that condition and shape the restructuring of work.

Chapter 2 investigates the contribution that the field of IPE can make to raising the visibility of alternative politicised understandings of social change. In many senses the field has defined itself in terms of its capacity to shed light on the dynamics of contemporary global social transformation, strenuously arguing that it captures change in a way that 'static' IR cannot grasp (see Strange, 1994). I sketch out the parameters of the claims made by so-called 'new IPE' scholars, and analyse their departure from 'orthodox' IPE perspectives. Though I use some of the insights of the 'new IPE' in the chapters that follow, I do so with criticism and caveats. There are further steps to be taken in prising open some of the doors that have been closed by dominant IPE ontologies, and I outline one of them here: an IPE of social practice. I propose that such a perspective can reveal the politics and contingency of globalisation as it is characterised by contests over the reality and representation of social change. First, a sensitivity to the historicity and contingency of global social change serves to uncover the diverse interpretations and experiences of restructuring within and across state-societies, firms and worker groups. Second, attention to the webs of power that surround and suffuse a programme of global restructuring challenges the notion that a prescribed 'best practice' such as labour flexibility is merely a matter for apolitical technical adaptation. Finally, an emphasis on the 'everydayness' of the restructuring of work brings the rarefied world of global finance, production and technology into a domain where it can be opened up to debate and contest. The IPE of 
social practice perspective is further developed in the chapters that follow, focusing on the restructuring debates within state-societies, firms and the daily lives of workers.

Taken together, chapters 3 and 4 explore the distinctive meanings of globalisation that are constructed through the restructuring programmes of different state-societies. I argue that state-societies debate and represent the problematic of globalisation in ways that are historically specific, and that interventions are made on the basis of these representations. Chapter 3 discusses the representation of globalisation underpinning British programmes of 'hyperflexibility' in the restructuring of work. The chapter addresses the 'national capitalisms' debate, exploring the making of a distinctively British capitalism, and discussing the contemporary discursive remaking of a 'global Britain'. I am particularly concerned here to use the IPE of social practice to reveal the tensions and contradictions of British hyperflexibility.

Chapter 4 moves to consider the restructuring debate taking place in German state-society. In popular and academic discourse Germany is often presented either as a proving ground for globalisation (the assumption being that the state-society may be forced to abandon its distinctive social market model in the face of global forces), or as a rebuttal to globalisation (the assumption being that the institutions and practices actively resist neo-liberal restructuring). In this chapter I argue that perceptions of the German relationship to globalisation, both inside and outside the state-society, are contradictory and contested. I explore the historical institutions and practices of state, capital and labour that have made possible particular programmes of restructuring in Germany. The contemporary restructuring of working practices is discussed, revealing the dominant negotiated programme of 'flexicorporatism'.

In the context of the globalisation of production, MNCs have been most commonly depicted as the key vehicles of global transformation. They have, however, tended to be considered as unitary 'non-state' actors, that is to say defined in terms of identifiable agency that is significant because of its 'bargaining power' with states (see Stopford and Strange, 1991; Strange, 1996). Chapter 5 opens up the presumed unity of the MNC to explore the social power relationships that constitute this 'global actor'. Defined in terms of the relationships between corporate managers, financiers, shareholders, suppliers and a diverse range of worker groups, the firm represents a site of contest in the ascription of meanings and realities of globalisation. Chapter 6 extends the inquiry into the contested nature of restructuring in production and work by exploring the concrete everyday experiences of workers. In line with an IPE of social practice approach, the chapter explores the everyday practices of work that variously enable, contest or confound the emerging social relations of globalisation. How do workers, broadly defined, engage with processes of global restructuring? What are the patterns of tension and co-ordination between different worker groups? As firms intensify their efforts to outsource 
production functions, what are the implications for unprotected workers? Overall, this chapter takes the analysis of the restructuring of work beyond a discussion of the politics of states and firms, toward an increased visibility for the concrete experiences of workers who are differentially positioned in the IPE of work.

In essence, the argument presented in this book seeks to extend the politicisation of globalisation beyond the image of direct street demonstrations and protests. The 'Seattle effect' is an undeniably significant feature of the contemporary contests surrounding globalisation. However, it is but one element of a much broader acknowledgement that globalisation is political by its very nature, not least as a result of its intertwining with the thoughts and actions of our everyday lives. Multiple modes of contestation can be revealed that open up both the concept and the experience of globalisation to political inquiry for instance the politics of the making of particular policies of restructuring, the politics of accommodation and compromise that enable particular forms of restructuring, and the politics of tension and resistance that confound and transform a restructuring agenda.

\section{Notes}

1 At the closure of the Fujitsu Corporation's semi-conductor plant in north-east England, the British Prime Minister, Tony Blair, announced during a television interview that 'regrettably there is little a government can do about the twists and turns of world markets in a global economy'. Under the heading of 'globalisation', a recent IMF paper noted that 'The last decade of the 20th century has been marked by immense changes in the world economy. The new phase of the technological revolution and the far-reaching internationalisation of capital have changed the patterns of economic performance ... Hence, on the eve of the new century, there are not only mounting structural problems, but several new issues that must be addressed properly' (2000b: 6). A similarly process-centred statement is made by Jonathan Freedland, for whom '... the economy has moved ahead of politics... vast global corporations influence every aspect of our day-to-day lives. Our only weapon is national governments - and these have proved themselves all but powerless' (The Guardian, 1 December 1999: 21).

2 A focus on broad shifts in industrial and workplace relations in ideal-type neo-liberal and neo-corporatist political economies would indicate that globalisation has indeed been accompanied by transformation in forms and modes of work. The 1998 British Workplace Employee Relations Survey reports that 47 per cent of firms located in Britain had no union members, a figure that has increased from 36 per cent in the 1990 survey (Cully et al., 1998). The number of part-time workers grew by 5.4 per cent over 1999 to total 24.9 per cent of total employment (European Industrial Relations Observatory (EIRO), 1999). Ninety per cent of British firms use subcontracting, 44 per cent use fixed-term contracts and 28 per cent use agency workers (EIRO, 1999). Figures for Germany show that trade unions lost 30 per cent of their membership between 1991 and 1998 (Institut der Deutschen Wirtschaft (IDW), 1999). Part-time working accounted for 18.3 per cent of total employment in Germany for 1999, while temporary work accounted for 10.8 per cent (EIRO, 1999). Eurostat figures suggest that the use of non-standard (temporary, part-time, fixed contract) employment has 
increased in all EU member states over the last decade, though this has been accompanied by varying degrees of legislative protection in different states (information sourced from personal enquiry to Eurostat, June 2000).

3 While the key elements of a project perspective have been discernible for some time, there are now analyses that explicitly refer to a globalisation project (see Rupert, 2000, ch. 3; McMichael, 2000; Sklair, 2001: 1). 